\title{
PROFESSIONAL MASTER AND ITS CHALLENGES
}

\author{
Mestrado profissional e seus desafios \\ Lydia Masako FerReira
}

A B STRACT

\begin{abstract}
Objective: To describe the history, origin, objectives, characteristics, implications, the questions of the evaluation form and some examples of the Professional Masters (MP), to differentiate the Academic Master, and identify the challenges for the next quadrennial assessment. Methods: The CAPES site on Professional Masters and documents and meeting area of reports from 2004 to 2013 of Medicine III were read as well as the reports and the sub-page of the area in Capes site. The data relating to the evaluation process and the Scoreboard of the other areas were computed and analyzed. From these data it was detected the challenges of Medicine III for the next four years (2013-2016). Results: The creation of the Professional Master is very recent in Medicine III and no Professional Master of Medicine III course was evaluated yet. Were described the objectives, assumptions, characteristics, motivations, the possibilities, the feasibility, the profile of the students, the faculty, the curriculum, funding, intellectual production, social inclusion, the general requirements of Ordinance No. 193/2011 CAPES and some examples of proposals, technological lines of scientific activities, partnerships and counterparties. The evaluation form of the MP was discussed, the need for social, economic and political intellectual production and the differences with the MA. It was also reported the global importance of the MP and its evolution in Brazil. From the understanding of the MP, Medicine III outlined some challenges and goals to be developed in the 2013-2016 quadrennium. Conclusion: Medicine III understood the MP as a new technological scientific horizon within the strict sensu post-graduate and full consistency with the area.
\end{abstract}

Key Words: Post-graduate education. Trends. Educational evaluation. Higher education. Health research evaluation. Program evaluation and research instruments. Staff development.

\section{INTRODUCTION}

Drofessional Masters (MP) creation was a natural progression of advances in science and technology whose needs go beyond the boundaries of each discipline pressing for cooperation of knowledge and research. It was from the multi, trans and interdisciplinary that the MP has emerged, focused on the productive world, the development of processes and products related to health services and partnership with private sector and the third sector. Requires approach with different social and political agents.

The guidelines of the National Postgraduate Plan (PNPG) 2011 to 2020 Health$^{1}$ present five axes and the MP provides consistency with all these guidelines: 1) expansion of the National System of Postgraduate (SNPG), which includes the quality, endogeny break, reducing asymmetries and leads to new forms of interaction with society; 2) new National Research Agenda and its association with postgraduate (PG) as a priority; 3 ) assessment of improvement and its expansion into other segments of the Science, Technology and Innovation (ST\&I) system, with consequent adjustments to the criteria of excellence, innovation and solidarity indicators; 4) multi, inter and transdisciplinary theme to think about the PG has stimulated and encouraged postgraduate programs (PPG) including MP; 5) support for basic education and other levels and types of education (as an example, Prof. Mat) ${ }^{1}$

Until recently, in the past decade, there was the concept that PG was focused on the training of human resources, teachers and researchers. In turn, they had as main objective the generation and dissemination of knowledge from the academic issues.

This concept has changed because despite the undoubted growth of quality and quantity of scientific production of Brazilian researchers (Brazil is the $13^{\text {th }}$ ranking of the world's scientific output) has not solved the problems of society, has not improved the health service (as reducing the costs of this care) and have not advanced in innovation generating economic and social sources. The health research was seen as merely academic forgetting its primary function is to improve the health of the population.

Advances in Science and Technology (S\&T) with the advent of new drugs, new equipment and new teaching models meant that research and innovation are imperative for the survival of enterprises and the economy. And innovation is nothing more than the combination of the corporate world with science. This has made higher education institutions to engage in knowledge creation and development of new technologies, contributing to the knowledge and practice can transform the lives of citizens.

And where there are more possibilities to exercise the so-called "Triple Helix" is exactly in MP. It is the interaction between the university, the company and the government in the innovation process. Each actor plays a key role in this process: the university with its knowledge generator; the company entering and investment; and the government with resources and incentives. ${ }^{2}$

\section{METHOD}

To access all the data for the MP, the CAPES website and PNPG guidelines have been read, as well as documents of Medicine III accessed on the sub-page of the area in the CAPES site..$^{3-8}$

The data relating to the evaluation process, the evaluation form of a MP course and data of the items and sub-items as Proposal, Faculty, the Student Body/Thesis, the Technological Scientific Production (PCT) and Social Inclusion in Medicine III were computed and analyzed ${ }^{7,8}$.

From these data it was detected the challenges of the area for the next four years (2013-2016).

\section{RESULTS}

The MP was established in December 20, 1996 by Law 9394; however, it was only in 2009 - 13 years after - the Ordinance No. 17 was created at 28 December 28, 2009 by CAPES 3 .

This document describes the MP mode as stricto sensu postgraduate training: 1) gains its own identity and value in itself, as responses to the needs and social demands (social contribution); 2) have its professional identity and therefore more focused on the social and technological development; 3) have dialogue with universities, local and regional community and the productive sector (whether in product development, either in staff training, whether in contributing to the solution of complex problems); and 4) contributes to the training with the scientific field in order to introduce new innovations and social technologies, improving the process/production ${ }^{3}$.

The MP enables the training of personnel for advanced professional practice transforming procedures and processes, through the incorporation of the scientific method. It enables the professional to work in scientific-technical and innovation activities; the training of qualified personnel for the appropriation and 
application of knowledge grounded in methodological rigor and scientific basis; and the development and permanent updating of advances in science and technology. Enables to apply them, focusing on the management, technical and scientific studies on applied research and to propose innovations and technological improvements for specific troubleshooting ${ }^{3}$.

So, we can define as MP stricto sensu postgraduate mode focused on the training of professionals through the study of techniques, processes, services or issues that meet any demand of the job/company market.

The goal of the MP is to contribute to the national productive sector in order to add a higher level of competitiveness and productivity of enterprises and organizations, whether public or private. It aims to improve the effectiveness and efficiency of public and private organizations through the troubleshooting and the generation and application of innovation processes.

As with the academic master's degree (MA), the MP also aims to train human resources, but with different focus. The MA aims to train researchers and teachers, and the MP train professionals able to develop new processes and techniques to be applied, aimed at the development or induction of new professional fields of activity in the area. The MP has a new identity.

The MP develop skills and competencies aimed at analyzing situations and problem solving through the rapprochement between the generation of knowledge and the development of technologies and innovations.

Making a metaphor, the MA is like a game of tennis (focus on the ball, that is, extreme focus for deepening the theme, and scientific production with high impact factor. And the MP resembles a dice game, ie horizon of $360^{\circ}$ for a wide view of the world and society using all their knowledge and expertise.

The motivations for the MP are:

1) the need to encourage the training of qualified professional teachers to develop activities and technical-scientific works on issues of public interest;

2) the need to identify potential actions for local, regional, national and international levels, by public and private agencies, companies, cooperatives and non-governmental organizations;

3 ) the need to address, particularly in the areas most directly linked to the labor market and the productive system, the demand for highly qualified professionals;

4) the possibilities to be explored in areas of latent demand for training of human resources for the socio-economic, political and cultural of the country;

5) the need for capacity building and training of researchers and professionals to increase the generation of inner potential, dissemination and use of scientific knowledge in the production of goods and services process in line with the Brazilian industrial policy;

6) social relevance, science and technology of advanced vocational training processes, as well as the necessary strengthening of relations between universities and the productive sector.

The MP provides the same degree and the same "rights" of the MA; however, its focus and way contemplate a horizon still little explored. The MP features may be more easily detected by analyzing the evaluation form of a MP course ${ }^{7,8}$.

The item Proposal of the Program of a MP includes activities in times compatible with continued professional work, training courses for execution/consumption of scientific research, basic content for skills in the field of scientific and technological research and needs to differentiate from specialized courses. Otherwise, the MA includes activities full time, compulsory subjects of a nuclear and elective curriculum and has clear differentiation with expertise.

The proposal should be appropriate to focus MP and central vision is the social and economic function. The fields of study should be focused on management, education and innovation, and there are research areas but on Technological Scientific Lines of Action.

The purpose of the proposal is intended to stimulate the training of qualified teachers to develop technical and scientific work in areas of public interest; meet the demand for highly qualified professionals in all fields of knowledge; train professionals to increase the potential for generation of innovation in the production of goods and services (with exchange companies); and aims at economic, social and political activities of the country.

The curriculum aims to associate disciplines and professional experiences to the demands of society, the identified trends or to be prospected (patents, processes, services...), building around issues of common interests between government and non-governmental higher education institutions in courses focused on entrepreneurship and technological development.

The planning of the curriculum includes the link between the current knowledge, the mastery of relevant methodology and application oriented to the specific professional playing field. These disciplines have interdisciplinary character and are not owned by the permanent faculty, the research group.

Therefore, the curricular structure of a MP includes public management, technological innovation and patents, new educational models, management and development management.

The MP faculty must consist of at least $60 \%$ with a doctoral degree; however, unlike the MA, some teachers with master's degrees and professionals with notable knowledge in the field can participate without academic degrees, but there is proof of their expertise in the area of the course. Thus, the faculty should consist of professionals recognized in their areas of knowledge, in skills and outstanding performance in relevant field to the proposal of the course.

Accordingly, the student body should have preferably experience in the professional field and preferably have grants funded by employers, with formal waiver of part of their activities for the implementation of the program. The CT research problems should be relevant to professional practice.

The MP of the students profile includes the ability to monitor and incorporate innovation processes, the ability to formulate projects aimed at answering the problems identified in professional practice and the ability to assess the impact of interventions (production of new knowledge enables organizational development). They must be qualified as trainer and promoter of change processes in their workspaces, applicability in developing products in the SUS and in Science and Technology Systems, in Federal and Regional Councils of Medicine and others being able to implement institutional strategies.

The analysis student production is more complex by the lack of uniform technique production indicators, since no MP course of Medicine III area was till now evaluated.

Despite the scientific and technological production is still difficult to analyze; it is known that scientific production of the MP has lower levels than those required for academic programs concerning the impact factor of the journals, since the MP there is a need to reconcile scientific production and technique.

The scientific and technological production (PCT) in the MP includes technical standards, protocols, services, products, articles, patents, intellectual property records, technical projects, technical publications; application development, learning materials and instructional and of products, processes and techniques; production of media programs, publishing, final reports of research, software, case studies, technical report with secrecy rules, technical operation manual, advisory committees, relevant advice, experimental protocol or application services, intervention proposal in clinical procedures or relevant service, application design or technological adaptation, prototypes for development or production of tools, equipment and kits, technological innovation projects.

Similar to the MA, there should be equal distribution of scientific and technical production among faculty, the PCT link with the area and the theme, integration with undergraduates and fundraising through partnerships and cooperation.

On the issue of Social Inclusion is included the potential impacts of training for improving the technical function, the innovation generating potential, the economic, political and social of the resulting MP product. 
Differentiation of MP's thesis or dissertation is the professional identity, ie more focused on the social and technological development, and create products, services and processes.

For feasibility analysis of MP's is to consider the formalization of commitments, the study of economic and financial viability, the infrastructure, the regiment and the approval and support of the institution.

Following, there is an example of MP course: training of qualified personnel for the performance of professional activities in the productive sector. The CT lines of action that have consistency with this program proposal are product development, development of herbal medicine, biotechnology and similar drugs, and validation of inputs for the surgical area, formulations for new products in surgery, new product development and training technical managers (quality control, research and development and production).

Another example of MP's proposal is the formation of human resources in Science and Technology recognized excellence and expertise in the areas involved in the industrial process, from design to the production of tools/equipment/software, through the various management-related areas. And the CT lines of action can be minimally invasive technologies and cryopreservation of tissues.

The MP funding should be linked to the type of demand, ministries of health, government agencies (state departments or municipalities), federal and state funding agencies, foundations support connected to public or private higher education institutions, development agencies international private companies that finance the tuition fees in return (eg company equipment or pharmaceutical industry), government agencies and national and international non-governmental organizations and scientific societies.

The MP for minimally invasive technology and realistic simulation in health, the University Unichristus located in the state of Ceará has made integration with related company by Regis Luiz de Moura (developer and manufacturer of mannequins and laparoscopic materials) in order to develop equipment and surgical instruments to bariatric surgery.

Another example of integration with government agency is provided by the Science MP Course Applied to Health of UNIVAS (the only MP who has reached note 4 on Medicine III), through the project "mattress Syncrus" for the prevention of pressure ulcers and "wheelchair running voice command access", integrated with INATEL (electronic excellence pole in telecommunications).

Another project was the integration with EPAMIG (MG agricultural research company) and CIMED R \& D (pharmaceutical industry), within the Technological Scientific Lines of Action in Herbal Medicines Wound. With this project UNIVAS aims the formation of many professionals to work at the various stages of the production chain of these drugs (since the development of high quality raw material in the production of seedlings certified by EPAMIG, development and production of drugs, till product application).

As key differentiators of MA, MP stands for the professional activity, being aimed to solve a professional problem, the needs and social demands, have focus and method used for learning. In summary, MA generates knowledge and uses that knowledge in MP and others to solve a problem or product development. It is a study on professional practice.

After this exhibition, it can be put the premises for MP: the training of professionals with ability to develop new techniques and processes; the character of terminally and clearly application; the proposal convergence of interests between academic higher education institutions and service providers; focused on the development or inducing new fields of professional activities; have the same MA quality but directed to professional training; have multidisciplinary, innovative and reconstruction character of the traditional model of teaching and not having academic identity (researcher), but professional identity focused on adding value.

The MP corresponds to the process for the analysis of situations and solving problems (PC and T\&I approach) with actions aimed at professional experiences of students and society.

Its characteristics imply three principles: flexibility, innovation and applicability. Aims to meet professional demands for economic, social and political development and joint PCT and human resources training with the market. The faculty should have experience in R\&D\&I and the curriculum should be directed to products and processes (eg public administration, patent ...).

Projects should include innovative strategies for teaching and learning and the student body come from different sectors of the economy (state departments, municipal, public higher education institutions, private sector companies and third sector).

Given these assumptions and features the MP has some implications: instructional design market-driven, well-added and knowledge; teachers must have expertise in Technological Scientific Lines of Action and be the common thread of knowledge and practices that the market demand requires; inter- and transdisciplinary curriculum and other levels; a global view of the world, society and science; the student body must be returned to the management, product and process; and developing indicators of social, economic and political impact.

Performing another metaphor, the MA is like an orchestra, whose system is hierarchical and pyramidal and the MP, a band whose system is integrated with improvisation and creativity.

The MP has a strong social focus, the formation of multiskilled managers in stimulating multi and interdisciplinary transcending the boundaries of traditional knowledge in the curriculum flexibility, curriculum focused on organizational analysis, stimulating R\&T, in cooperation with the public sector, private and third sector

The general, requirements of Ordinance No. 193/2011 CAPES are described below:

Proposals for new courses of professional master shall present:

1) adequacy of the proposal to the institutional development plan of the applicant and commitment of organizational leaders with initiative; clarity and consistency of the proposal, which must present indicators showing:

1a) qualification of teaching staff;

$1 \mathrm{~b})$ adequacy of the focus areas and projects;

1c) adequacy of the curriculum with their disciplines;

1d) terms of student selection criteria and justification for the profile of the required vocational training and the area of the stage of development in the country.

2) technical and scientific competence for the promotion of the course, demonstrating that the proposal was preceded by the formation and maturation of research groups with relevant intellectual production, in quantitative and qualitative terms, and able to provide training for students in the areas of concentration provided;

3) permanent faculty board that, in number, time basis to the program and academic qualification, be adequate to ensure the regularity and quality of teaching, research and guidance;

4) educational infrastructure and adequate research for the development of the planned activities, in terms of physical facilities, laboratories, experimental facilities and library;

5) infrastructure and access to updated computer equipment, the worldwide web and multimedia sources of information for teachers and students;

6) office infrastructure and administrative support.

The presentation of the document certifying the institutional commitment to the proposal is necessary and required.

According to Global Research and Development, a commitment to spending on R\&D\&l has been more than double the investment in the last 15 years, since 1996. In Brazil, many inducing actions have been carried out by the Financier of Studies and Projects (FINEP) through incubation of technology-based companies and other arrangements for the Foundation of São Paulo State support (FAPESP) through PITE/PIPE projects (for small business), the National Bank for Economic and Social Development (BNDES) and the Secretariat Professional and Technological Education (SETEC) 
The number of MP courses has increased over the years exponentially especially in the last five years (Figure 1).

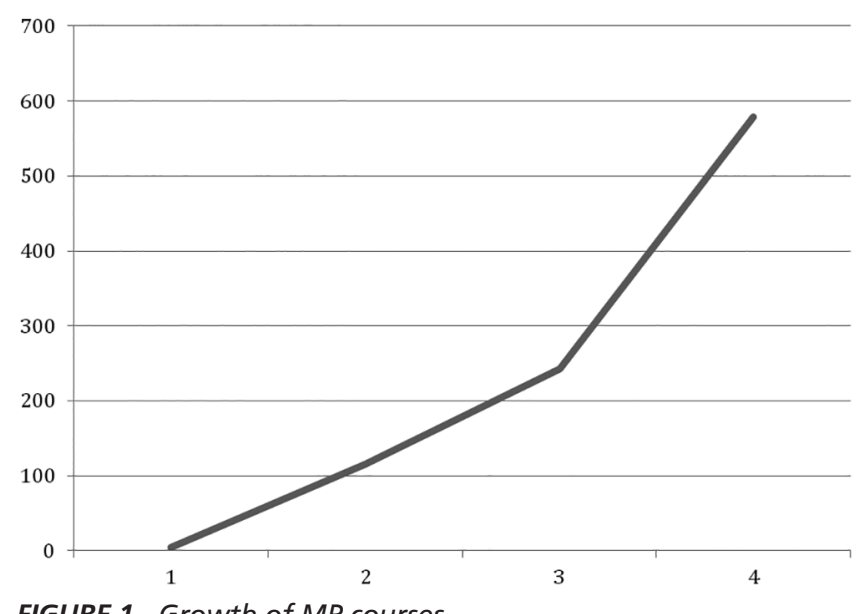

FIGURE 1 - Growth of MP courses

(Source: SNPG. 25/7/2014)

As expected, there is now greater concentration of MP in the Southeast (50\%) followed by the South (20\%) and Northeast (17\%) (Table 1). Medicine III has no stricto sensu courses (MA or MP) in the Midwest.

\begin{tabular}{|l|c|c|}
\hline & MP & $\%$ \\
\hline Centro-Oeste & 37 & 7 \\
\hline Nordeste & 99 & 17 \\
\hline Norte & 33 & 6 \\
\hline Sudeste & 288 & 50 \\
\hline Sul & 116 & 20 \\
\hline Total & 573 & 100 \\
\hline
\end{tabular}

TABLE 1 - Absolute and relative number of MP courses by region in Brazil (Source: SNPG; Actualization: 25/07/2014)

From the concept of MP, objectives, characteristics and motivations, Medicine III makes visible some challenges:

\section{Link PCT to the market}

Breaking paradigms and breaking with the traditional academic education still represents a challenge for all areas. The PCT without articulation with the market is infertile and to be profitable will need to develop products, services, equipment and processes for the benefit of society. The development of products, equipment, services and processes in the area requires the applicability of multi, inter and transdisciplinary and partnerships with industries and companies. The link of the academy now articulates science with the business world. A key feature to occur this joint is the cultural and structural change in educational institutions.

\section{Investment in technology and innovation}

Scientific societies would benefit qualitatively to carry out cooperation with the MP and in return the postgraduate studies program could benefit through grants to students, in partnership with the sponsors of the events. Similarly, it is important the involvement of public or private companies and the third sector, whose employees would benefit from the MP, not forgetting the traditional sources of funds, federal and state funding agencies.

\section{Increase the number of MP}

The number of MP courses has increased as shown in Figure 1 and Table 1, exponentially from 2009. The new coordination of areas of Capes took over in June 2011 for a three-year term. Thereafter we began detailed analysis of all data from PPG Medicine III to terms diagnosis of the area and to outline the goals and challenges for the triennium. One of the challenges was to reduce regional asymmetry of Medicine III. Thus, on 10 and 11
June 2012, pursuing this goal, we were (Ruy Marques, Assistant Professor of Operative Technique of UERJ; José Cerqueira Bras, Professor at UNESP Anesthesiology; Lydia Masako Ferreira, Coordinator Medicine III and Director Evaluation of CAPES, Professor Livio Amaral) at Federal University of Ceará welcomed by Professor Paulo Leitão de Vasconcelos, Professor of Surgery of the institution. The meeting involved all the Deans of the North, Northeast and Midwest for the sole purpose of increasing PPG in these regions. The result of this effort was minimal because few institutions interested in creating masters and doctoral courses.

Thus, during the Annual Meeting of Medicine III held since 2011, it has emphasized the need for PPG terms in the North and Midwest, hitherto non-existent. The surgical community has responded to this concern and has started phase in which the institutions of the North and Northeast requested talks about Medicine III and its challenges. For the first time, were created PPG in the North: MP two courses, one in UEPA and another in UFAM. In these four years, it was created seven MP courses (both in the North region, two in the Northeast region, three in the Southeast region) and one MA course at UFPR. Still, we continue with the challenge of creating an academic or professional PPG, still nonexistent in Centerwest region.

Many professionals in the surgical specialty still unaware of the real meaning of the MP, as new technological scientific horizon. Still entrenched academic culture, "in the box". Technological advances within the area requires the advancement of scientific and technological research, with great consistency with MP features. Once the professionals of surgical specialties incorporate the culture to analyze the social, economic and political impact of scientific and technological production, progress in creating new MP will be exponential.

\section{Professional Doctorate creation}

Demand for the Professional Doctorate (DP) has been very great in all areas due to the exponential growth of the MP. In the world, many countries have DP for over 50 years. As an example, 50\% of English universities already have 109 DP and Australia 171. In the US, there were about 50 types of professional doctorate in early 1990. Currently, there are over 72 DP.

\section{Development of criteria for evaluating MP}

Certainly the biggest challenge of all areas for the next four years when the first MP will be evaluated, is the implementation of evaluation criteria. Medicine III has met with the MP Sub-Committee of Evaluation and began this task since July 2014 when the coordination of the area was nominated again for another management.

As stated above, these criteria is based on standard and intellectual rigor, as high as the MA, but different from it, because its characteristics are completely different.

The difference in weight during the evaluation form of the items include increase in the weight in Faculty, Intellectual Production and Social Inclusion (25\%, 35\% and 15\% respectively), and decreased in the student body/thesis (20\%).

On May 18 and 19, with the Professional Assistant Professor Jorge Fouto Matias, was discussed and created another Sub-Committee of Evaluation Criteria for MP, whose members should be the coordinating teachers of the MP of Medicine III, beyond coordination of the area and the Professional Assistant.

\section{MP Network (PROFCIR)}

As the ProfMat with 4,174 registered students and 917 already formed, the ProLetras with 848 registered students, Profes with 315 registered students, ProfBio still in pilot phase, other areas have set up their network in MP in 2014 (Art, History and Public Administration).

Medicine III as well as other medicines have trouble creating MP Network due to the feature area does not belong exclusively to a specialty. Only Medicine III includes Anesthesiology, Cardiac Surgery, General Surgery, Pediatric Surgery, Plastic Surgery, Thoracic Surgery, Vascular Surgery, Gastrosurgery, Gynecology, 
Neurosurgery, Gynecology, Ophthalmology, ENT, Orthopedics and Traumatology, Urology and Operative Technique. The difficulty of the logistics of a MP network with 16 specialties has delayed the creation of this MP.

Four years ago, in 2011 was tried to hold a ProfCir, uniting societies of Plastic Surgery, Gastrosurgery, Ophthalmology and Orthopedics and carry out a master plan for MP network in the surgical area. However, there was no receptivity of hand by one of the presidents of these specialties, which made us to reflect on the existing fragility when changing presidents. We would have to include in the constitution and bylaws of each association involved, commitment clause with the continuity and sustainability of the course.

This challenge is still the goal in this management which ends in 2017.

\section{CONCLUSION}

Medicine III understood the MP as a new technological scientific horizon within the strict sensu PG and with full consistency with the area.

\section{RESUMO}

Objetivo: Descrever o histórico, a origem, os objetivos, as características, as implicações, os quesitos da ficha de avaliação e alguns exemplos do Mestrado Profissional (MP), sua diferenciação com o Mestrado Acadêmico, e detectar os desafios para o próximo quadriênio de avaliação. Métodos: $\mathrm{O}$ site da CAPES sobre Mestrado Profissional e os documentos e relatórios de reuniões de área a partir de 2004 até 2013 da Medicina III foram lidos assim como os relatórios e a subpágina da área no site da Capes. Os dados referentes ao Processo de Avaliação e à Ficha de Avaliação das outras áreas foram computados e analisados. A partir desses dados foram detectados os desafios da Medicina III para o próximo quadriênio (2013-2016). Resultados: A criação do Mestrado Profissional é muito recente na Medicina III e nenhum curso de Mestrado Profissional da Medicina III foi avaliado. Foram descritas a definição, os objetivos, as premissas, as características, as motivações, as possibilidades, a viabilidade, o perfil do alunado, do corpo docente, a estrutura curricular, o financiamento, a produção intelectual, a inserção social, os requisitos gerais da Portaria CAPES n 193/2011 e alguns exemplos de propostas, linhas de atuação científico tecnológica, parcerias e contrapartidas. Foi discutida a ficha de avaliação do MP, a necessidade do impacto social, econômico e político da produção intelectual e as diferenças com o MA. Foi relatado também a importância mundial do MP e a sua evolução no Brasil. A partir do entendimento do MP, a Medicina III traçou alguns desafios e metas para serem desenvolvidas no quadriênio 2013-2016. Conclusão: A Medicina III entendeu o MP como um novo horizonte científico tecnológico dentro da pós-graduação stricto sensu e com total coerência com a área.

Descritores: Educação de pós-graduação/tendências. Avaliação educacional. Educação superior. Avaliação da pesquisa em saúde. Avaliação de programas e instrumentos de pesquisa. Desenvolvimento de pessoal.

\section{REFERENCES}

1. PNPG 2011-2020. Ministério da Educação. Disponível em: http://portal.mec.gov.br/index.php?option=com_docman\&task=doc_download\&gid=8759\&ltemid $=$

2. Valente L. Hélice tríplice: metáfora dos anos 90 descreve bem o mais sustentável modelo de sistema de inovação. Conhecimento \& Inovação 2010. 6:1.

3. Fundação CAPES - Ministério da Educação. Mestrado Profissional: o que é?. Disponível em: http://www.capes.gov.br/avaliacao/ sobre-a-avaliacao/mestrado-profissional-o-que-e. Acesso em 13/02/2015

4. Fundação CAPES - Ministério da Educação. Disponível em: http:// www.capes.gov.br/avaliacao. Acesso em 13/02/2015.

5. Fundação CAPES - Ministério da Educação. Mestrado e Doutorado Reconhecidos. Disponível em: http://conteudoweb.capes.gov.br/ conteudoweb/ProjetoRelacaoCursosServlet?acao=pesquisarRegiao. Acesso 17/02/2015
6. Fundação CAPES - Ministério da Educação. Avaliação. Entrada no SNPG. Mestrado Profissional. Disponível em: http://www.capes. gov.br/avaliacao/entrada-no-snpg-propostas/mestrado-profissional. Acesso 12/03/2015

7. Documento de área e Comissão da Trienal 2013. Área Medicina III. Disponível em: http://capes.gov.br/images/stories/download/avaliacaotrienal/Docs_de_area/Medicina_III_doc_area_e_ comiss\%C3\%A3o_att08deoutubro.pdf. Acesso em 15/11/2014.

8. Fundação CAPES - Ministério da Educação. Medicina III. Disponível em: http://www.capes.gov.br/component/content/article/44-avaliacao/4633-medicina-iii . Acesso em 15/11/2014.

Received on: 19/02/2015

Accepted for publication: 12/09/2015

Conflict of interest: none

Source of funding:

Address for correspondence:

Lydia Masako Ferreira

lydiamferreira@gmail.com 